УДК 352/354-1

https://doi.org/10.52058/2708-7530-2021-10(16)-182-191

Сидоренко Наталя Олегівна кандидат наук 3 державного управління, доцент кафедри менеджменту, Інститут підготовки кадрів Державної служби зайнятості України, вул. Нововокзальна, 17, м. Київ, 03038, тел.: (044) 536-14-85, e-mail: sidnat@ukr.net, https://orcid.org/0000-0001-8734-9704

\title{
ПОДОЛАННЯ НЕГАТИВНИХ НАСЛІДКІВ ГЛОБАЛЬНОЇ ПАНДЕМІЇ COVID-19 У ДІЯЛЬНОСТІ СФЕРИ НАДАННЯ АДМІНІСТРАТИВНИХ ПОСЛУГ
}

Анотація. У статті здійснено дослідження мінімізації негативних наслідків глобальної пандемії COVID-19 у сфері надання адміністративних послуг. Розглянуто діяльність центрів надання адміністративних послуг, яку можна визначити як напрям діяльності органів місцевого самоврядування для реалізації власних та делегованих повноважень у публічному управлінні, що спрямований на забезпечення умов для реалізації прав суб'єктів звернення.

Обгрунтовано, що у Законі України «Про адміністративні послуги» закріплено назву «центр надання адміністративних послуг», які можна вважати стратегічно важливими об'єктами інфраструктури, що обслуговують велику кількість громадян та юридичних осіб, надаючи їм адміністративні, місцеві, соціальні та інші послуги. Основна мета їх діяльності зробити такі послуги доступними, швидкими й якісними.

Визначено, що у 2020 році світ пережив глобальну катастрофу під назвою пандемія коронавіруса COVID-19 яка змусила всіх змінити свій звичний спосіб життя, ці обставини також вплинули на роботу ЦНАП. В умовах епідеміологічної ситуації деякі Центри були змушені короткостроково повністю припинити роботу, а більшість 3 них істотно обмежили контакти 3 відвідувачами, або перейшли у дистанційний формат обслуговування.

Охарактеризовано, що ЦНАП веде якісну роботу 3 інформування та консультування суб'єктів звернення, пріоритетом якої $\epsilon$ впровадження електронних послуг. Електронні послуги, це ідеальне рішення в ситуації, що склалася в умовах пандемії. У червні 2021 року уряд схвалив виділення 231 млн. грн. субвенцій з державного бюджету місцевим бюджетам на розвиток мережі Центрів Дія. «Дія» - це модернізовані ЦНАП, місце, де ви можете вирішити всі необхідні питання за одне відвідування - соціальні, пенсійні, паспортні та комунальні. Це такий простий i зрозумілий єдиний сервіс для отримання державних та інших послуг. Як додаток і портал, які об'єднують в єдиному електронному вікні усі послуги, що надаються державою громадянам і бізнесу.

3'ясовано, що сфера адміністративних послуг не найкритичніша в той 
період, який сьогодні переживає Україна i світ. При цьому існують певні адміністративні послуги, доступ до яких важливий під час карантину. Поширенню коронавірусу COVID-19 можна запобігти, скоротивши міграцію людей і контакти між ними, а також вакцінуванням.

Ключові слова: коронавірус COVID-19, пандемія, карантин, адміністративні послуги, ЦНАП, суб'єкти звернення, центри «Дія», органи місцевого самоврядування, публічне управління, територіальна громада.

Sydorenko Natalya Olehivna Candidate of Sciences in Public Administration, Associate Professor of The Management Department, Institute of Personnel Training of the State Employment Service of Ukraine, Novovokzalna St., 17, Kyiv, 03038, tel.: (044) 536-14-85, e-mail: sidnat@ukr.net, https//orcid.org/0000-0001-8734-9704

\section{OVERCOMING THE NEGATIVE CONSEQUENCES OF THE COVID-19 GLOBAL PANDEMIC IN THE FIELD OF ADMINISTRATIVE SERVICES}

Abstract. The article examines the minimization of the negative effects of the global pandemic COVID-19 in the field of administrative services. The ASC activity is considered, which can be defined as the activity of local self-government bodies for realization of own and delegated powers in public administration, which is aimed at providing conditions for realization of rights of subjects of appeal.

It is substantiated that the Law of Ukraine "On Administrative Services" enshrines the name "administrative services center", which may provide strategically relevant infrastructure facilities that provide a large number of citizens and legal entities, providing them with administrative, local, social and other services. The main purpose of their activity makes such services accessible, fast and high-quality.

It is determined that in 2020 the world experienced a global catastrophe called the pandemic of the coronavirus COVID-19 and forced everyone to change their usual life styles, these circumstances also affected the work of the ASC. Due to the epidemiological situation, some Centers were forced to stop working completely, and most of them significantly limited contacts with visitors or switched to remote service format.

It is characterized that the ASC conducts quality work on informing and consulting service customers, the priority of which is the introduction of electronic services. Electronic services are an ideal solution in a pandemic situation. In June 2021, the government approved the allocation of 231 million UAH in subventions from the state budget to local budgets for the development of a network of Diia centers. "Diia" is a modernized ASC, a place where you can solve all the necessary issues in one visit social, pension, passport and utility. This is such a simple and clear single service for obtaining public services. As an application and a portal that will unite in a single electronic window all the services provided by the state to citizens and businesses.

It was found that the sphere of administrative services is not the most critical in

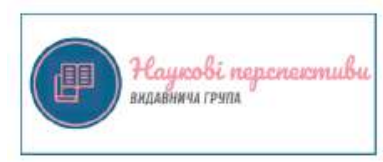


the period that Ukraine and the world are going through today. However, there are certain administrative services, access to which is important during quarantine. The spread of COVID-19 coronavirus can be prevented by reducing human migration and contact between them, as well as vaccination.

Keywords: coronavirus COVID-19, pandemic, quarantine, administrative services, ASC, subject of apply, centers "Diia", local authorities, public administration, local community.

Постановка проблеми. Уряд України робить все можливе для ефективної боротьби з пандемією коронавірусу COVID-19 в нашій країні. 3 цією метою введені обмежувальні заходи по боротьбі 3 розповсюдженням коронавіруса COVID-19 на рівні територіальних одиниць. Поширення коронавіруса COVID-19 відбувається в багатьох країнах світу, в результаті чого бізнес й економічна активність стрімко знижуються, що негативно відображається й на обсягах виробництва, доходах державного i місцевого бюджетів, рівні безробіття та інших соціально-економічних показниках. Постановою Кабінету Міністрів України від 11 березня 2020 р № 211 «Про запобігання поширенню на території України гострої респіраторної хвороби COVID-19, спричиненої коронавірусом SARS-CoV-2» введено карантинні заходи по боротьбі 3 розповсюдженням коронавірусу COVID-19 [1]. Цим нормативно-правовим документом вводяться карантині обмеження, що впливають не тільки на діяльність органів публічного управління, а й на органи місцевого самоврядування, а також на діяльність ЦНАП. Карантинні обмеження і економічна криза, викликані пандемією гострого респіраторного захворювання COVID-19, негативно відбилися на системі надання адміністративних послуг населенню. Тому, 3 огляду на вищесказане, існує необхідність вивчення надання адміністративних послуг населенню України в умовах пандемії COVID-19, щоб в подальшому забезпечити зручність, своєчасність й доступність їх отримання.

Аналіз останніх досліджень і публікацій. Окремі питання дослідження адміністративних послуг в Україні розглядалися в роботах науковців, зокрема: Авер'янова В.Б., Голосніченка І.П., Коліушка .Б., Писаренко Г.М., Тимощука В.П., Шкурата I.B. та ін. Однак, питанням впливу пандемії COVID-19 на адміністративні послуги є мало дослідженими.

Мета статті - дослідити вплив пандемії коронавірусу COVID-19 на процес надання адміністративних послуг в Україні.

Виклад основного матеріалу. Сфера надання адміністративних послуг регулюється нормами Закону України «Про адміністративні послуги» від 6 вересня 2012 р., який визначає основні поняття, зокрема, «адміністративна послуга» - результат здійснення владних повноважень суб'єктом надання адміністративних послуг за заявою фізичної або юридичної особи, спрямований на набуття, зміну чи припинення прав та/або обов'язків такої особи відповідно до закону. Також у Законі визначено, що «центр надання адміністративних послуг» 
(далі ЦНАП, Центр) це постійно діючий робочий орган або виконавчий орган (структурний підрозділ) органу місцевого самоврядування або місцевої державної адміністрації, що зазначені у частині другій цієї статті, в якому надаються адміністративні послуги згідно з переліком, визначеним відповідно до цього Закону. У ЦНАП послуги надаються адміністратором центру, у тому числі шляхом його взаємодії з суб'єктами надання адміністративних послуг. У виняткових випадках (якщо послуги у ЦНАП не можуть бути надані адміністратором або таке їх надання є значно гіршим для інтересів суб'єктів звернення та/або публічних інтересів) окремі адміністративні послуги можуть надаватися через ЦНАП посадовими особами суб'єктів надання адміністративних послуг на підставі узгоджених рішень 3 органом, який прийняв рішення про утворення центру надання адміністративних послуг. ЦНАП, утворений як постійно діючий робочий орган, забезпечує надання адміністративних послуг суб'єктам звернення із залученням до його роботи посадових осіб окремих виконавчих органів (структурних підрозділів) органу, який прийняв рішення про утворення центру надання адміністративних послуг. Центри мають власні найменування та можуть мати символіку. Окремо від найменування та символіки центри мають право використовувати позначення «Центр Дії» [2].

Центр надання адміністративних послуг з погляду споживача це таке місце (будівля/приміщення; орган влади), де можна отримати максимально необхідний набір адміністративних послуг у комфортних умовах. [3].

ЦНАП - стратегічно важливі об’єкти інфраструктури, які щодня обслуговують велику кількість громадян, надаючи їм адміністративні та інші державні послуги. Основна мета їх діяльності - зробити надання таких послуг доступним, швидким, комплексним й якісним. Багато послуг, що надаються через ЦНАП, життєво важливі для людей: вони вимагають реєстрації народжень і смертей, проживання, власності або бізнесу. Для ведення бізнесу необхідно отримати різні реєстраційні, дозвільні дії та інше. Через ЦНАП може надаватись кілька сотень адміністративних, соціальних, місцевих послуг, а також інші послуги, наприклад комунальних установ. У переліки послуг включені всі основні напрямки послуг - реєстрація та зняття з обліку за місцем проживання; оформлення паспортних документів (в тому числі біометричних документів для виїзду за кордон); реєстрація бізнесу і нерухомості; державна реєстрація земельних ділянок; архітектурні проблеми; питання опіки та піклування, благоустрою та ведення бізнесу [4].

Але сфера надання адміністративних послуг постійно удосконалюється. Завдяки роботі міжнародних програм, що підтримують розвиток ЦНАП в Україні, у більшості діючих ЦНАП переліки послуг можуть включати до 14 груп послуг, наприклад: паспортні, державна реєстрація бізнесу, державна реєстрація майнових прав, соціальні послуги, реєстрація місця проживання/передування особи, місцеві, земельні послуги, видача водійських посвідчень, комплексні послуги - єМалятко та інші. 
ЦНАП веде якісну роботу з інформування, залучення та консультування суб'єктів звернення, пріоритетом якої $є$ впровадження електронних послуг. Відповідно до законодавства має бути розроблений офіційний веб-сайт або вебсторінка ЦНАП, де громадяни можуть знайти необхідну інформацію про послуги, що надаються у ЦНАП (місце розташування та режим роботи, контактну інформацію, перелік послуг, реквізити для оплати послуг та перелік необхідних документів, записатися на консультацію, чи прийом / видачу документів). Інформаційні сервіси на сайті про статус сервісу і статус черги дозволяють отримувати оперативну інформацію. Сортування послуг з життєвих ситуацій (всього 18 напрямків обслуговування) дозволяє клієнтам легше знаходити необхідну інформацію про послуги, що їх цікавить. Інфографіка роботи центру в режимі онлайн на сайті відображає загальну кількість наданих послуг i консультацій. А також кількість людей, яким були надані послуги 3 моменту запуску системи. Для зручності громадян на сайті можна створити особистий кабінет резидента або записатися в дошкільний заклад. Тут також працює послуга «Онлайн-консультація». Мобільний додаток для смартфонів «Дія», який синхронізується з сайтом ЦНАП, дозволяє, крім іншого, отримувати інформацію про всі сервіси ЦНАП і переглядати статус тієї чи іншої послуги [5; 6].

Однак у 2020 році світ стикнувся 3 негативним впливом глобальної пандемія коронавірусу COVID-19, яка змусила всіх змінити свій звичний спосіб життя: перебувати в громадських місцях в масках, зберігати соціальну дистанцію, використовувати антисептики, мити руки та інше. Звичайно, ці обставини також вплинули на роботу ЦНАП. В умовах епідеміологічної ситуації деякі Центри були змушені повністю припинити роботу (короткостроково), а більшість 3 них істотно обмежили контакти 3 відвідувачами та почали розвивати дистанційні форми роботи.

3 березня 2020 року в Україні введено карантин і ряд інших обмежувальних заходів у зв’язку 3 пандемією коронавіруса. При цьому державні органи продовжили роботу по задоволенню потреб населення. Міністерство цифрової трансформації України підготувало список адміністративних послуг, які можна було б отримати від ЦНАП в екстрених випадках під час карантину. Тому що неможливість отримання певних послуг позбавляє громадян можливості здійснювати свої права і підтримувати гідний рівень життя. Відповідну постанову Кабінет Міністрів України прийняв 20 березня 2020 р. [7]. Але навіть в цій ситуації залишається в силі загальна норма Закону «Про адміністративні послуги» [3], згідно з якою перелік послуг в ЦНАП визначається органом, що сформував ЦНАП, тобто органами місцевого самоврядування (це їх компетенція), цей список може бути скоректований в залежності від місцевих потреб.

Перелік адміністративних послуг, які надаваються через ЦНАП під час карантину є наступним: оформлення паспорта громадянина України; вклеювання фотокартки до паспорта при досягненні 25 чи 45 років; комплексна послуга єМалятко для батьків новонароджених; видача дозволу на участь у дорожньому 
русі транспортних засобів, параметри яких перевищують нормативні; погодження маршрутів руху транспорту під час перевезення небезпечних вантажів; реєстрація, перереєстрація та зняття з обліку транспортних засобів, що належать закладам охорони здоров'я або у зв'язку 3 втратою техпаспорту; видача посвідчень водія замість втраченого чи викраденого; державна реєстрація народження фізичної особи та іiі походження; державна реєстрація смерті; субсидія на оплату житлово-комунальних послуг і т.д. [7].

Особливої уваги потребує аналіз організації взаємодії в умовах карантину 3 суб’єктами звернень та з суб’єктами надання адміністративних послуг. Протягом останніх років адміністративні послуги надавалися в ОМР ЦНАП за попереднім записом. Вибираючи такий принцип взаємодії з відвідувачами виходили 3 наступного: у зв'язку з величезним попитом на адміністративні послуги, що надаються через ЦНАП, виникла необхідність в моніторингу завантаженості адміністраторів, 3 одного боку, а 3 іншого - необхідність дотримання максимально допустимого часу очікування для іфдвідувачів - не більше 15-20 хвилин.

Закон України «Про адміністративні послуги» визначає мінімізацію кількості відвідувань як один 3 принципів організації надання адміністративних послуг. Щоб забезпечити дотримання цього принципу у ЦНАПах запускають call-центри, адміністратори якого надають вичерпні консультації 3 отримання адміністративних послуг, список документів, а також записують на прийом. Таким чином, фізичним особам не потрібно відвідувати Центр для отримання консультації або запису на прийом. В умовах карантину робота call-центру стала особливо актуальною.

Третього листопада 2020 року Верховна Рада України прийняла Закон «Про внесення змін до деяких законодавчих актів України щодо оптимізації мережі та функціонування ЦНАП та удосконалення доступу до адміністративних послуг, які надаються в електронній формі» (далі - Закон) [5]. Законом суттєво змінено редакцію статті 12 Закону «Про адміністративні послуги» (щодо діяльності ЦНАП). Чіткіше прописано статус ЦНАП, його ключові ознаки та підходи до організації роботи, які вже склалися на практиці. У визначенні поняття і статусу ЦНАП (ч. 1 ст. 12) акцентовано, що ключовою ознакою ЦНАП $є$ надання визначеного відповідно до цього Закону переліку адміністративних послуг. Можливість застосування різних моделей (механізмів) надання адміністративних послуг у ЦНАП:

1) безпосередньо адміністратором;

2) через адміністратора, шляхом його взаємодії 3 суб’єктами надання адміністративних послуг (СНАП);

3) суб'єктами надання адміністративних послуг, тобто їх посадовими особами.

Сьогодні, як за рахунок делегування повноважень органам місцевого самоврядування (коли орган, який формує ЦНАП, i суб’єкт, що надає

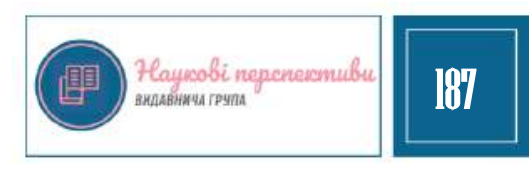


адміністративні послуги, збігаються в одній установі), так і через інформаційні технології, існує значно більше послуг, які можна назвати «швидкими», тобто те, що може бути надано негайно. У законі використовується поняття «мобільний віддалений адміністратор робочого місця». Це було зроблено для підвищення правової визначеності роботи так званого «мобільного ЦНАП», а також для обслуговування громадян в форматі «виїзного адміністратора».

Закон також визначає поняття «пересувного/віддаленого робочого місця адміністратора» ЦНАП, за допомогою якого можна надавати послуги у дуже віддалених населених пунктах [5]. Така тенденція організації роботи існує і в бізнес середовищі (наприклад, так працюють банки), що оптимізує витрати на утримання мережі та персонал. Таким чином, ЦНАП сприятимуть розвитку електронних послуг, також у ЦНАП рекомендується створювати місця самообслуговування громадян або збільшення їх кількості (у великих ЦНАП). При цьому необхідно надавати відвідувачам консультаційну підтримку, щоб вкладення в організацію були ефективними.

Законодавством передбачено обов'язкове поетапне створення ЦНАП в усіх територіальних громадах. При цьому пріоритетом № 1 у 2021 році визначено «заміщення» ЦНАП РДА на ЦНАП ОМС у всіх «старих» районних центрах (станом на 01.01.2020). Ця робота має бути завершена до 1 січня 2022 року.

Електронні послуги - ідеальне рішення в ситуації, що склалася. I нинішня криза до цього підштовхує ще швидше. У червні 2021 року уряд схвалив виділення 231 млн. грн. субвенцій з державного бюджету місцевим бюджетам на розвиток мережі Дія Центрів. Міністерством цифрової трансформації України було відібрано 165 спільнот, які отримають фінансову допомогу від держави. Це забезпечить 5 мільйонів українців сучасними державними послугами.

Дія Центри - це модернізовані ЦНАП, місце, де громадянин може вирішити всі необхідні питання за одне відвідування - соціальні, пенсійні, паспортні та комунальні. Мобільний застосунок «Дія» - це такий простий і зрозумілий єдиний сервіс для отримання державних послуг. Метою Уряду є протягом трьох років оцифрувати всі державні послуги [6].

Крім електронних документів і деяких сервісів, у грудні 2020 року постраждалі від карантину ФОП і співробітники змогли отримати грошову допомогу від держави через додаток [8]. Спочатку роботи порталу «Дія» українці могли віддалено отримати в мережі 27 державних послуг, зокрема: стати підприємцем, змінити вид діяльності або припинити їі; оформити довідку про відсутність судимості; оформити допомогу при народженні дитини або щомісячне відшкодування вартості послуг з догляду за дитиною до трьох років; подавати позов; допомогу з безробіття; зареєструвати автомобіль або отримати послуги з оформлення водійських документів, дозволів або отримати виписки 3 реєстрів. До 2024 року уряд поставив мету вивести 100\% державних послуг в онлайн.

Окрім доцільності запровадження електронних сервісів в умовах пандемії, 
окремі науковці вбачаються й інші тенденції, що будуть впливати на сферу публічного управління в цілому, і на сферу надання адмінпослуг зокрема, а саме: поява нового формату глобалізації, радикальні зміни виробничих ланцюгів створення суспільних продуктів та логістики, трансформації ціннісних орієнтацій учасників глобального виробництва, зміна ландшафту суспільного поділу праці та виникнення трансформацій на регіональних та глобальних ринках праці [9].

Висновки. Негативний вплив глобальної пандемії спричинив об’єктивні зміни у роботі сфери надання адміністративних послуг України. Існують послуги які потребують постійного виконання, за будь-яких обставин, наприклад, реєстрація смерті та народження, паспортні послуги, питання реєстрації бізнесу та нерухомості, соціальні та інші. Отже, на рівні держави та територіальних громад необхідно забезпечити постійний доступ суб'єктів звернень до послуг під час карантину.

Відомо, що поширенню коронавірусу COVID-19 можна запобігти, скоротивши міграцію людей i контактів 3 ними. Тому, на нашу думку, $\epsilon$ доцільним розробка та затвердження на законодавчому рівні змін роботи ЦНАП під час пандемії, а саме норм і положень, які мають регламентувати роботу ЦНАП в режимі «он-лайн» - надання консультацій, подання відсканованих копій документів для отримання послуг, запис в електронну чергу для отримання послуг а також можливість дистанційної роботи персоналу.

ЦНАП є місцем, де одночасно перебуває чисельна кількість осіб, тому при організації його роботи в умовах пандемії бажано, щоб відвідувачі перебували в Центрі необхідний час для заповнення та підписання заяв, документів або отримання результату. Спілкування з відвідувачами максимально перенесено на віддалені сервіси: call-центри, чат-боти, онлайн-консультанти і т. д.

На завершення, можна визначити, що напрямами подальших наукових досліджень у цій сфері рекомендовано відслідковувати подальший вплив пандемії на формування нових компетентностей у працівників ЦНАП (для дистанційної роботи або роботи з он-лайн сервісами). Знаходити та поширювати кращі практики задля вирішення проблем у сфері надання адміністративних послуг в умовах пандемії.

\section{Лimepamypa:}

1. Постанова Кабінету Міністрів України «Про запобігання поширенню на території України гострої респіраторної хвороби COVID-19, спричиненої коронавірусом SARS-CoV-2». від 11 березня 2020 р № 211. URL: https://zakon.rada.gov.ua/laws/show/211-2020-\%D0\%BF\#Text

2. Закон України «Про адміністративні послуги» від 6 вересня 2012 р. № 5203-VI. URL: https://zakon.rada.gov.ua/laws/show/5203-17\#Text

3. Як створити ЦНАП - досвід інституційного створення ЦНАП у рамках Програми «ULEAD 3 Свропою». (березень 2021) : Посібник. URL: https://tsnap.ulead.org.ua/wpcontent/uploads/2021/04/Well-functioning-ASC_2021.pdf.

4. Бригілевич I., Лепьошкін І. Практичний посібник «Діяльність ЦНАП та оцінка якості надання адміністративних послуг» підготовлено в рамках діяльності. м. Київ, 2017 р. 40 с.

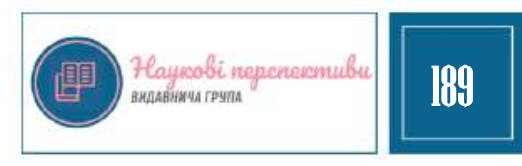


5. Закон України «Про внесення змін до деяких законодавчих актів України щодо оптимізації мережі та функціонування центрів надання адміністративних послуг та удосконалення доступу до адміністративних послуг, які надаються в електронній формі» від 3 листопада 2020 року № 943-IX. URL: https://zakon.rada.gov.ua/laws/show/943-20\#Text

6. Офіційний сайт Міністерство та Комітет цифрової трансформації України. URL: https://thedigital.gov.ua/cnap/Perelik_usih_naselennih_punktiv.

7. Постанова Кабінету Міністрів України «Перелік адміністративних послуг, які надаватимуться в ЦНАП під час карантину» від 20 березня 2020 року. URL: https://www.kmu.gov.ua/news/perelik-adminposlug-yaki-nadavatimutsya-v-cnap-pid-chas-karantinu

8. Офіційний сайт Е-Україна. URL: https://eukraine.org.ua/ua/news/pidsumki-2020-proektroku-diya-rozpovidayemo-pro-golovnij-dodatok-ukrayinciv.

9. Шкурат I.В., Сидоренко Н.О. / Подолання негативних наслідків глобалізаційних викликів у сфері зайнятості через використання мережі ЦНАП на локальному рівні /Шкурат I.В., Сидоренко Н.О. // Теорія та практика державного управління: збірник наукових праць; ISSN 1727-6667 Харків 4, 2020. С. 169-176. 212 с.

\section{References:}

1. Postanova Kabinetu Ministriv Ukrayiny` «Pro zapobigannya poshyrennyu na terytorii Ukrainy gostroi respiratornoi hvoroby COVID-19, sprychynenoi koronavirusom SARS-CoV-2» vid 11.03.2020 [Resolution of the Cabinet of Ministers of Ukraine " On prevention of the spread of acute respiratory disease COVID-19 caused by coronavirus SARS-CoV-2 on the territory of Ukraine" of 11.03.2020] (2020, March 11). Retrieved from: https://www.kmu.gov.ua/news/perelik-adminposlugyaki-nadavatimutsya-v-cnap-pid-chas-karantinu [in Ukrainian].

2. Zakon Ukrayiny` «Pro administraty`vni poslugy`» vid 6.09.2012 №5203-VI. [Law of Ukraine "On Administrative Services” of 6.09.2012 № 5203-VI] (2012, September 6) Retrieved from: https://zakon.rada.gov.ua/laws/show/5203-17\#Text [in Ukrainian].

3. Yak stvoryty CNAP - docvid instytutsiynogo stvorennya CNAP u ramkah Programy «ULEAD z Evropoyu». (berezen 2021)': Posibny`k; [How to create an ASC- the experience of institutional creation of the ASC by the U-LEAD with Europe Program: Manual; March 2021 URL: https://tsnap.ulead.org.ua/wp-content/uploads/2021/04/Well-functioning-ASC_2021.pdf.] [in Ukrainian].

4. Bry`gilevy`ch, I., Lep`oshkin, I. (2017) Prakty`chny`j posibny`k «Diyal`nist` CzNAP ta ocinka yakosti nadannya administraty`vny`x poslug» pidgotovleno v ramkax diyal nosti [Practical manual "ASC activities and quality assessment of administrative services" was prepared in the framework of the activity]. Ky`yiv, 40 p. [in Ukrainian].

5. Zakon Ukrayiny` «Pro vnesennya zmin do deyaky`x zakonodavchy`x aktiv Ukrayiny` shhodo opty`mizaciyi merezhi ta funkcionuvannya centriv nadannya administraty`vny’x poslug ta udoskonalennya dostupu do administraty`vny`x poslug, yaki nadayut`sya v elektronnij formi» vid 3.11.2020 №943-IX [Law of Ukraine "On Amendments to Certain Legislative Acts of Ukraine Concerning Optimization of the Network and Functioning of Centers for Provision of Administrative Services and Improvement of Access to Administrative Services Provided in Electronic Form” of 3.11.2020 № 943-IX] (2020, November 3). Retrieved from: https://zakon.rada.gov.ua/laws/show/943-20\#Text [in Ukrainian].

6. Oficijny`j sajt Ministerstvo ta Komitet cy`frovoyi transformaciyi Ukrayiny` [Official website of the Ministry and the Committee for Digital Transformation of Ukraine]. Retrieved from: https://thedigital.gov.ua/cnap/Perelik_usih_naselennih_punktiv [in Ukrainian].

7. Postanova Kabinetu Ministriv Ukrayiny «Perelik administraty`vny`x poslug, yaki nadavaty`mut`sya v CzNAP pid chas karanty`nu» vid 20.03.2020 [Resolution of the Cabinet of Ministers of Ukraine "List of administrative services to be provided to the ASC during quarantine" of 20.03.2020] (2020, March 20). Retrieved from: https://www.kmu.gov.ua/news/perelik-adminposlugyaki-nadavatimutsya-v-cnap-pid-chas-karantinu [in Ukrainian]. 
8. Oficijny j sajt E-Ukrayina [Official site of E-Ukraine]. Retrieved from: https://eukraine.org.ua/ua/news/pidsumki-2020-proekt-roku-diya-rozpovidayemo-pro-golovnijdodatok-ukrayinciv [in Ukrainian].

9. Shkurat, I., Sydorenko, N. (2020) Podolannya negatyvnyh naslidkiv globalizatsiynyh vyklykiv u sferi zaynyatosti cherez vykorystannya merezi CNAP na lokal'nomu rivni [Overcoming the negative consequences of globalization challenges in the field of employment through the use of the ASC network at the local level] Theory and practice of Public Administration : collection of scientific works; Kharkiv 4, 2020. 212 p. [in Ukrainian]. 